\title{
The Concept of Tafakkur in The Qur'an in Responding to Covid-19
}

\author{
$1^{\text {st }}$ Siti Arie Fithriah ${ }^{1}, 2^{\text {nd }}$ Dewi Khairani ${ }^{2}, 3^{\text {rd }}$ Asep Saepudin Jahar ${ }^{3}, 4^{\text {th }}$ Imam Subchi $^{4}$, \\ $5^{\text {th }}$ Imam Sujoko ${ }^{5}, 6^{\text {th }}$ Fuad Jabali ${ }^{6}$ \\ \{arie.fithriah17@mhs.uinjkt.ac.id ${ }^{1}$, dewi.khairani@uinjkt.ac.id ${ }^{2}$, asepjahar@uinjkt.ac.id ${ }^{3}$, \\ imam.subchi@uinjkt.ac.id ${ }^{4}$, imam.sujoko@uinjkt.ac.id ${ }^{5}$, fuad.jabali@uinjkt.ac.id ${ }^{6}$ \}
}

Sy arif Hiday atullah State Islamic University of Jakarta, Indonesia ${ }^{1,2,3,4,5,6}$

\begin{abstract}
Thinking is one of the human privileges compared to other of God. In the uslub of the Qur'an, the word of this thought is expressed in the term tafakkur. Other terms that have some similarities with it are ta'ammul and tadabbur. Tafakkur activity or thinking well and deeply is the key to opening the door of divine light, the door of all knowledge, the beginning or basis for the vision of conscience, and the path to ma'rifatullah so that it reaches a good understanding of Allah SWT. The urgency of tafakkur for a muslim is a form of self-reflection so that he can become a servant who is always grateful. Tafakkur is very much beneficial if done accordingly. However, tafakkur has limits, among them: they cannot bear testimony about the substance of God, do not harm, and tafakkur should make us more confident to God.
\end{abstract}

Keywords: Tafakkur, Al-Qur'an, Coronavirus, Covid-19.

\section{Introduction}

Starting from a local case, Covid-19 spreads throughout the world one after another using transmission called imported cases from outside the area of origin or local transmission between residents. So far, the events that have occurred for the first time in connection with Covid-19 do not seem to provide a complete picture of this virus. Conclusion so far, the analysis of experts suggests that Covid-19 is more likely to survive in dry, low-temperature areas even though the virus is also endemic in countries with the opposite temperature and humidity conditions. It is also more susceptible to causing death in the aged population. continue. However, there are also residents in this age group who have managed to recover, and a baby has also died from Covid-19. The first series of events also show the efforts of experts to find this antivirus as quickly as possible. So far, these efforts have not yielded the results as expected. In hindsight, the series of the early emergence of Covid-19 are familiar to the world community. China is listed as the country that first reported cases of Covid-19 in the world. For the first time, China reported the presence of this new disease on December 31, 2019. At the end of 2019, the office of the World Health Organization (WHO) in China received a notification about the existence of a similar type of pneumonia whose cause is unknown. The acute respiratory infection that attacks the lungs was detected in the city of Wuhan, Hubei Province, China. According to authorities, some of the patients were traders operating at the Huanan Fish Market. 
Over time, the search said, Covid-19 cases had appeared before. Refer to37th WHO report on the Covid-19 situation, 26 February 2020, China's first confirmed case of Covid-19 was on December 8. However, this information also depends on the initiatives of countries that provide disease information to the global health agency. A report published on the page The Lancet medical journal by Chinese doctors from Jin Yin-tan Hospital in Wuhan, who treated some of the earliest patients, cited the date of the first known infection as of December 1, 2019. Information on the origin of the emergence of Covid-19 is still running backward. On December 16, doctors at the Wuhan Central Hospital sent samples from another patient with persistent fever for laboratory testing. These results suggest the virus resembles severe acute respiratory syndrome (severe acute respiratory syndrome /SARS).

On December 30, 2019, Ai Fen, a doctor who is also the head of the hospital's emergency room department, uploaded an image of the laboratory report on Chinese social media. The image was reposted and circulated by another doctor, Li Wenliang. Later, they were reprimanded by the local police for being considered "spreading rumors". Li Wenliang became known as a whistleblower for the Covid-19 case[1].

Based on the problem in the problem described above, the analysis of this paper targeted people behavior's in covid-19 pandemic. This study uses a religion-based approach as an alternative to treat the pandemic effect on Moslem.

\section{Research Method}

This study uses descriptive qualitative research methods because this method is an attempt to understand the various concepts found in the research process. The research is used in natural object conditions, where the researcher is the key instrument, the sampling of data sources is done purposively and snowball, the data collection technique is by triangulating (combined) data analysis is inductive/qualitative, and the results of qualitative research emphasize the meaning of generalization. As for the research data collection, namely observation, interviews, and documentation studies. Then the data is reduced, displayed, and presented by research procedures.

The descriptive data analysis model used in this research, described in Fig.1 below.

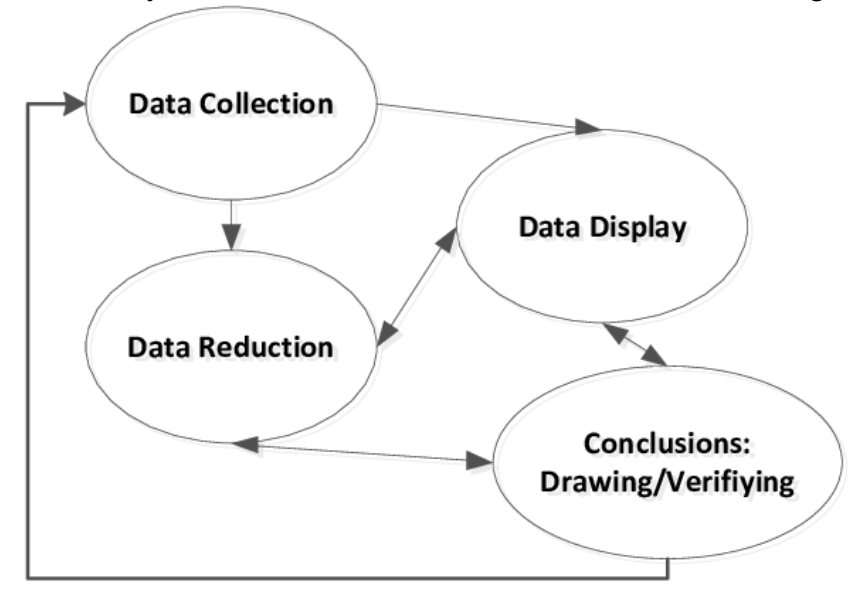


Fig. 1. Qualitative descriptive data analy sis model of Miles dan Huberman[2]

\section{Literature Review}

One of the most important characteristics that must be possessed by a person who believes in Allah SWT is the ability to see the signs of Allah's power through His Angels. As he praised His greatness. Allah created all the creatures in this universe as a reminder and guidance of Allah's greatness, not as a useless spectacle. There is not a single creature created by Allah that is useless. Creatures with each other are all related to each other which functions to maintain the order of the systems that exist in this universe. Understanding these characteristics is called Tafakkur. If a believer can see the greatness and power of Allah in every creature and in His creation in the sense of being able to meditate, then he will always feel close to Allah.

Take the time or fill in the time for tafakkur is one of the interesting ways for the wisdom expert and the taqwa expert in presenting the greatness of Allah in his heart [3]. Tafakkur here means contemplating the greatness and power of Allah in creating and supervising and maintaining the order of the system that He created in this universe. With tafakkur he will discover the secrets behind all God's creatures and always grow the greatness of Allah in his heart.

Tafakkur is an important component that must be owned for every believer[4] because Tafakkur is a reflection of a believer. He can see all good and bad through it. That was A1Hasan's explanation[5]. With Tafakkur, a believer will know the nature and secrets of His creatures or an event that occurs around him. He will also know the good and bad that is contained in every commandment and prohibition. It is not said that a true believer is intelligent if he does not dhikr and meditates on what is in this universe, as revealed in the Qur'an:

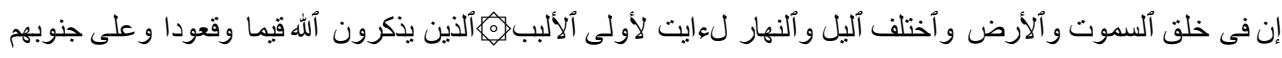

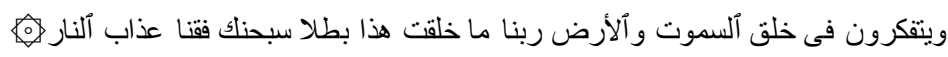

Meaning: "Verily in the creation of the heavens and the earth, and the alternation of night and day there are signs for those who are wise $\&$ (namely) those who remember Allah while standing or sitting or lying down and they think about the creation of the heavens and the earth. (While saying): "O our Lord, you did not create this in vain, Glory to you, so save us from the torments of hell."

The above verse in addition to the advice for humans to practice meditation also shows one of the characteristics a believer must have, namely always remembering Allah in any state and condition, whether standing, sitting, or lying down [5].

In the previous research about Covid-19 and its relation to religion as mention by [6], we know that people are unpredictable and how religion weaves itself through the cross-section of human life is inconceivably mind-boggling. Surfacing such human worth elements is an open commitment. Similarly, as wellbeing authorities attempt to clarify their proposals, so specialists in the logical investigation of religion need to surface religion-abetted esteem decisions that sway practices pertinent to viral spread. 
Bentzen in his research [7] describe amid emergency, people tend to go to religion for stress help and clarification. The 2020 COVID-19 pandemic is no special case: The interest in religion has risen drastically since the beginning of the pandemic with political pioneers and self-sorted out gatherings asking their kindred residents to supplicate.

Jaja, et al [8] in his study on the South Africa region mention that strict and social exercises of any structure must be confined as of now. The guideline affirming 50 people for every entombment presents a chance for the spread of COVID-19. Thus, just close relatives ought to be permitted to cover their friends and family, it likewise refers to that the rules by the WHO should additionally be carefully actualized.

The previous research about Tafakkur by [9] discovered that the tafakkur on Covid-19 infection in the point of view of the Islamic religion delivered discoveries through, to be specific; first, isolate, to be specific confining the territory influenced by the plague is a fitting activity; Second, show restraint; Third, be benevolent and buckle down; Fourth, ask a great deal and pray.

\section{Result and Discussion}

Imam Sya'rawi commented in his book that humans have a responsibility to understand the natural surroundings or the universe to arrive at the true truth. Contemplating the natural phenomena that occur in the universe will provide enormous benefits to reveal all the signs of the greatness and power of Allah SWT who will lead humans to become creatures who are always obedient, submissive, and obedient to the Creator, namely Allah SWT. However, there are important limits that must not be crossed and must be considered when going to meditation, namely, we must not think about, contemplate, or think about anything related to the Substance of Allah SWT.

There is a hadith from the Prophet's wife that explains how to protect yourself when an epidemic occurs:

$$
\begin{aligned}
& \text { عن عائشة زوج النبي صلى الله عليه وسلم أنها أخبرتنا أنها سألت رسول الله صلى الله عليه وسلم عن الطاعون فأخبر ها نبي }
\end{aligned}
$$

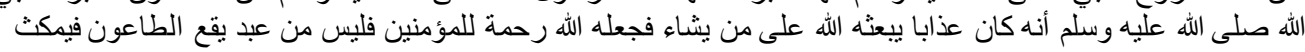

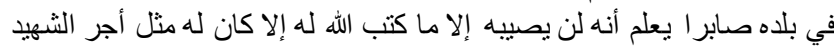

"From Siti Aisyah RA, he said, I asked The Prophet Muhammad about tha'un, then The Prophet Muhammad told me, in the past, tha'un is punishment that Allah sends to whomever He wants, but Allah makes it a blessing for believers. So no one gets hit by tha'un, then he keeps himself at home patiently and hopes for His pleasure while realizing that tha'un will not happen to him other than it has become Allah's provision for him, surely he will get a reward like the reward of a martyr. ,"Narrated by Bukhari, Nasa'i and Ahmad).

In general, this hadith describes physical and mental efforts when disease outbreaks such as Covid-19 have emerged throughout the world, including Indonesia. The sentence "In the past, tha'un was a punishment from Allah" shows that the plague that occurred during the time of the Prophet Muhammad up to now was not punishment but a test or trial that Allah imposes on those whom He wills, so we are not worthy to accuse those affected. the Covid-19 pandemic as a person affected by punishment. No one will be able to avoid the plague if Allah has been destined, and the plague will not befall those whom Allah SWT protects. On the 
contrary, the plague is used as a blessing for people who have always believed that nothing happens in this universe but on the arrangement of the Supreme Being.

In this hadith, The Prophet Muhammad guided an outbreak, including:

\subsection{Do not leave the house (Stay at Home)}

The sentence "then he restrained himself at home" is a sunnah exemplified by the Prophet Muhammad when an epidemic broke out. The slogan \#stay at home \# is a method to cut the spread of the Covid-19 outbreak, because if the crowd is not restricted, surely the spread of Covid-19 will be even more massive. Stay at home is a restriction on small-scale movement within the family circle but is effective in minimizing the spread of Covid-19. As for the regional scale, the Regional Government imposes PSBB or Large-Scale Social Restrictions. With this policy, all human activities are transferred to their respective homes. Students/students study at home, workers/employees work at home, even religious activities are moved to the house. Some mosques and other places of worship in the red zone have be en temporarily restricted, such as Friday prayers being replaced by Zuhr prayers at home, and other religious activities that trigger crowds. We need to emphasize that we are not leaving the mosque / mushalla but praying at home to carry out the sunnah during the plague.

The phrase "refrain at home" is interpreted as a prohibition on visiting areas affected by Covid-19 or leaving the areas affected by Covid-19 to other areas as exemplified by The Prophet Muhammad. One of the implementations of this hadith is the prohibition of going home to and from areas where the spread of Covid-19 is indicated. The ban on going home is part of the sunnah as an effective solution to stop the pace of the coronavirus outbreak with a lockdown method.

\subsection{Be patient}

The sentence "patiently and hopefully be pleased with Him" is a sunnah or guidance of the Prophet Muhammad when holding back at home. Patience, in the sense of refraining from leaving the area affected by the plague until the end of the Covid-19 pandemic, solely hopes for the pleasure of Allah and believes that the plague is a commandment of Allah SWT's destiny without complaining and despair. The person who stays at home during the plague will undoubtedly get the reward of being martyred even though he does not die. Therefore, we need to strengthen our intention during the Covid-19 outbreak, while being kind to God, not leaving our physical and mental efforts, and then be patient and put our trust in Him.

Patience does not mean total submission, but patience must be accompanied by maximum physical and mental effort to prevent the spread and the bad effects of the virus, including frequent ablution, maintaining cleanliness, diligently washing hands, maintaining body immunity, applying social/physical distancing. distancing), do not leave the house except in urgent circumstances, and are accompanied by tawakkal to Allah SWT.

\subsection{Improve Worship}

The sentence "and hope for His pleasure" is a sunnah in the form of mental efforts in dealing with the Covid-19 outbreak. During the quarantine period at home, let us improve the 
quality of worship and always pray to Allah SWT so that the Covid-19 pandemic will soon disappear from Indonesia. In this holy month, the house can be used as a center of worship during an outbreak, where all series of worship can be done individually or in the congregation with the core family members at home, such as recitation of the Qur'an, Dhuha prayers, Tarawih and Witir prayers, dzikir, breaking the fast. fasting, and other worship activities. We can take advantage of the momentum of Ramadan during Covid-19 to decorate homes with worship activities so that houses can be witnesses of worship and make houses full of blessings. Once again,

This hadith is closed with the sentence "surely he will get a reward like the reward of a martyr", that is, for anyone who is struggling to deal with the Covid-19 outbreak by staying at home with full patience, unresponsiveness, and carrying out worship properly will undoubtedly gain rewards like those of people who died struggling to defend the religion of Allah SWT.

\section{Conclusions}

Regarding the Covid-19 coronavirus outbreak, as a believer, it is better if apart from doing quarantine or "social distancing" efforts, they also improve our spirituality. If you can meditate further, as a Muslim all this plague is a mercy, a warning for those who think, to continue to make it as wasilah or a way to keep a lot closer to Allah SWT, so that when the level of submission is high, you will feel calm and with all your efforts. and pray for salvation also to Allah SWT, by always involving Him, and hope that all this plague will end, and the cause can also be found soon, Ins ha Allah. Allah knows best.

Acknowledgments. This paper was supported by PPM for KKN-DR year 2020. 


\section{References}

[1] "Rangkaian Peristiwa Pertama Covid-19 - Bebas Akses." https://bebas.kompas.id/baca/riset/2020/04/18/rangkaian-peristiwa-pertama-covid-19/ (accessed Aug. $14,2020)$.

[2] M. A. Miles, "Miles and Huberman (1994)- Chapter 4.pdf," in Qualitative Data Analysis: An Expanded Sourcebook, 1994.

[3] Dr. Hamzah Ya'coup, Tingkat Ketenangan dan Kebahagiaan Mukmin. Jakarta: Pustaka Atisa, 1992.

[4] A. I. Ismail, Pilar-Pilar Takwa Doktrin, Pemikiran, Hikmat, dan Pencerahan Spiritual,. Jakarta: Rajawali Pers, 2009.

[5] A. A. M. B. A. A.-A. Al-Qurtubi, Tafsir Al-Qurthubi. Jakarta: Pustaka Azzam, 2008.

[6] W. J. Wildman, J. Bulbulia, R. Sosis, and U. Schjoedt, "Religion and the COVID-19 pandemic," Religion, Brain and Behavior. 2020, doi: 10.1080/2153599X.2020.1749339.

[7] J. S. Bentzen, "In Crisis, We Pray: Religiosity and the COVID-19 Pandemic," Covid Econ., 2020.

[8] I. F. Jaja, M. U. Any anwu, and C. J. Iwu Jaja, "Social distancing: how religion, culture and burial ceremony undermine the effort to curb COVID-19 in South Africa," Emerging Microbes and Infections. 2020, doi: 10.1080/22221751.2020.1769501.

[9] I. Indriya, "Konsep Tafakkur Dalam Alquran Dalam Menyikapi Coronavirus Covid-19," SALAM J. Sos. dan Budaya Syar-i, 2020, doi: 10.15408/sjsbs.v7i3.15048. 